\title{
Packaging perspective of milk and dairy products
}

\author{
Mario Ščetar, Irena Barukčić*, Mia Kurek, \\ Katarina Lisak Jakopović, Rajka Božanić, Kata Galić
}

Faculty of Food Technology and Biotechnology, University of Zagreb, Pierottijeva 6, 10000 Zagreb, Croatia *Corresponding author: Phone: +3851 4605039; E-mail: ibarukcic@pbf.hr,

\section{Abstract}

Packaging of dairy products develops continuously along with advances in material technologies, which are in turn a response to demands of consumers. This article aimed to give an overview of currently available dairy packaging systems. Novel dairy packaging systems include new packaging technologies such as the modified atmosphere packaging (MAP) that is widely used nowadays, especially for dairy product like cheese. Application of edible packaging could significantly reduce the costs of cheese packaging by reducing the amount of usually required packaging material. Nanomaterials and active packaging might be useful for extending the shelf life of dairy products by reducing material permeability or negative sensory characteristics of batch processing. Forms of active packaging relevant to dairy foods include oxygen scavenging, carbon dioxide absorbers, moisture and/or flavour/odour taints absorbers; releasing compounds (carbon dioxide, ethanol, antioxidants and/or other preservatives); maintaining temperature control and/or compensating temperature changes and antimicrobial packaging. Antimicrobial packaging is gaining interest from packaging scientists and industry due to its potential for providing quality and their safety benefits. The greatest challenge from the ecological point of view is biodegradable packaging. The main challenges for low waste materials are the durability of the packaging correlated with product shelf life as well as the ecological perspective.

\section{Key words: dairy products, MAP, antimicrobial packaging, smart packaging, edible coatings}

\section{Introduction}

Basic role of dairy packaging, as well as for any other food product, is to provide a physical barrier to food in order to prevent the item from different damage (mechanical, physical, microbial contamination, etc.) and to maintain the best product quality. In the ideal case the packaging should constrain weight and nutrient losses as well as help in extending shelf life of packed item. 
The process of manufacturing dairy products is sophisticated but the most determining factors that influence textural and the rheological properties of the products are content of milk fat and milk proteins, thickener type, heat treatment, incubation temperature, rate of acidification, and added stabilizers. The optimized amounts of ingredients, quality level of products, cutting time and safety-assurance can be determined non-invasively and non-destructively in the production line. Therefore, the final yield of the manufacturing process is affected by different parameters such as the characteristics of milk, type of instrumentation, time of processes, number of processes, type and quality of additives and ingredients, and packaging conditions (Ciron et al., 2011; Pang et al., 2015; Mohammadi et al., 2017).

Historically, the packaging of fluid milk started around the $19^{\text {th }}$ century with the invention of the condensed milk production and it referred to the application of glass bottles. In 1932 the first plastic-coated milk carton was used (Alvarez and Pascall, 2011). As the time went by, and with the development of food industry new packaging methods were also introduced. Modern milk and dairy products are packaged into different materials considering numerous factors such as product type, processing and storage conditions, requirements for handling and the end purpose. Most frequently glass and/or plastic bottles, laminates (multilayer materials), pouches, plastic tubs, cans and other containers are used. All of those have one thing in common - they have to be printable and must provide all product information required by the legislation (Karaman et al., 2015). Although it is generally required for packaging material to be inert and not to interact with the packed dairy product, current trends are focused on development of packaging that include certain interactions in order to extend the shelf life. That way is provided through so called active, smart or intelligent packaging concept. The aim of this paper is to give a concise review of packaging materials and methods usually applied in the dairy industry with special emphasis on novel technologies.

\section{Packaging materials convenient for dairy products}

When choosing packaging material for dairy products, various important factors need to be considered such as toxicity, compatibility with the product, impact resistance, maintenance of sanitation, odour and light protection, chemically inactivity, shape and weight requirements, marketing appeal, printability and cost (Karaman et al., 2015). The nature and the characteristics of the dairy product to be packaged define the selection of the appropriate packaging material and method. For example, if the product is susceptible to oxidation (such as butter) a selected material needs to have high barrier properties toward oxygen in order to enable the declared shelf life. Similarly, if the dairy product needs to be thermally treated after it has been packaged, the chosen material has to be heat tolerant. Some of the most frequently used materials for packaging of selected dairy products and their permeability properties are presented in Table 1.

\section{Food-package interaction}

If the choice of the packaging material is improper, undesirable interactions with the packed dairy product might occur resulting in serious concerns about their safety. Over the past 10-15 years several food safety issues on migration of hazardous substances from packaging material into dairy products have been recorded. Consequently, numerous studies focused on the examination of possible migrants into dairy products, mostly into milk powder, liquid infant formulae, liquid milk and cheese (Wu et al., 2010). In the past decade the problem of migration of bisphenol $A(B P A)$ in various dairy products was recorded.

Thereby, it must be highlighted that BPA is one of the most widely used synthetic compounds worldwide and can adversely impact human health, especially infants (Jalal et al., 2018). BPA is usually applied in production of specific polycarbonate plastic and epoxy resins coatings for cans. Since it is highly lipophilic, BPA can easily migrate from the container or the plastic lining of cans to the foods like milk, condensed milk or various ready- 
to-eat liquid formulae especially at temperatures above $50{ }^{\circ} \mathrm{C}$. Consequently, such packaged products are contaminated sources of BPA and lead to human exposure and bioaccumulation (Wu et al., 2010; Wong et al., 2017). Kang and Kodo (2003) measured BPA concentrations between 21 and 43 ng $\mathrm{g}^{-1}$ in milk, yogurt, butter, cream, condensed and flavoured milk, while it was not detected in noncanned products. BPA was also detected in milk samples from some European countries like Greece, Sweden or Portugal. Especially canned milk or infant formulae were identified to contain elevated levels of BPA (Maragou et al., 2006; Cunha et al., 2011). Cao and Corriveau (2008) detected BPA in disturbing concentrations between 2.27-10.2 $\mathrm{ng} \mathrm{g}^{-1}$ in all samples of canned liquid infant formulae.

Although such food is the main source of human intake of BPA, it is still unclear whether the BPA levels to which people are currently exposed are exceeding the safety limit. Besides BPA, there are also some other compounds whose occurrence in food products was also recorded. For example, the likelihood of monomer and oligomer migration increases when a plastic is exposed to high temperatures during thermal processing. This includes different plasticizers, antioxidants, slipping agents, heat stabilizers etc. Low-density polyethylene (PELD) is one of mostly widely used packaging materials and is often applied for cheese packaging. However, it might contain several additives which could migrate into the product and act adversely to food safety. Sanches Silva et al., (2007., 2009) detected considerable amounts of hazardous com- ponents such as diphenylbutadiene (DPBD) and butylated hydroxyl-toulene (BHT) in milk powder and soft cheeses packaged into PE-LD. Similarly, Cruz et al., (2008) showed that DPBD and BHT had higher migration rate in packed cheese (gouda, $4.5 \%$ - $35 \%$ fat content) than it was predicted in model system. This points out the importance of testing in real food products that will surely become one of the main interests in toxicology tests in the very near future.

Intended or unintended interactions between dairy and packaging materials may cause significant sensory changes in packed food product. Additionally, this may also occur because of material failures as well as from failure of materials to protect the product integrity or quality (Duncan et al., 2009). Packaging materials can also significantly influence the physico-chemical properties of probiotic dairy foods.

One of the most important is definitely acidity during storage (Jayamanne and Adams, 2004) whose changes can directly affect the product quality and ultimately limit the consumers acceptability. Saint-Eve et al., (2008) compared $4 \%$ fat yogurts to $0 \%$ fat yogurts stored in glass, polypropylene (PP) and polystyrene (PS) as packaging materials, and reported that the fat content of yogurt can act as an aroma solvent and reduce absorption into packaging. 
TABLE 1. Packaging materials commonly used for dairy products (Adopted from: Alvarez and Pascall, 2011)

\begin{tabular}{|c|c|c|c|c|c|c|c|}
\hline \multirow[t]{2}{*}{ Material } & \multirow{2}{*}{ 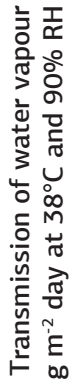 } & \multicolumn{3}{|c|}{$\begin{array}{l}\text { Gas permeability } \\
\mathrm{cm}^{3} \mathrm{~m} \mathrm{~m}^{-2} \text { day }^{-1} \mathrm{~Pa}^{-1} \\
\text { at } 25^{\circ} \mathrm{C} \text { and } 50 \% \mathrm{RH}\end{array}$} & \multirow[t]{2}{*}{ Advantages } & \multirow[t]{2}{*}{ Disadvantages } & \multirow[t]{2}{*}{ Products } \\
\hline & & $\mathrm{O}_{2}$ & $\mathrm{~N}_{2}$ & $\mathrm{CO}_{2}$ & & & \\
\hline Glass & Low & Low & Low & Low & $\begin{array}{l}\text { Impermeable, easily } \\
\text { recycled, inert }\end{array}$ & $\begin{array}{l}\text { Heavy weight, } \\
\text { breakable, high energy } \\
\text { costs of manufacturing }\end{array}$ & $\begin{array}{l}\text { Fresh milk, } \\
\text { yogurt, cream }\end{array}$ \\
\hline Metal & Low & Low & Low & Low & $\begin{array}{l}\text { Excellent gas barrier, } \\
\text { rigid, easily recycled }\end{array}$ & $\begin{array}{l}\text { Requires coatings } \\
\text { to prevent corrosion }\end{array}$ & $\begin{array}{l}\text { Milk powder, } \\
\text { condensed and } \\
\text { evaporated } \\
\text { milk }\end{array}$ \\
\hline \multicolumn{8}{|l|}{ Films } \\
\hline $\begin{array}{l}\text { Polyvinylidene } \\
\text { chloride, } \\
\text { PVDC }\end{array}$ & 3.1 & $\begin{array}{l}2.28 \\
\times 10^{-10}\end{array}$ & $\begin{array}{l}2.28 \\
\times 10^{-10}\end{array}$ & $\begin{array}{l}1.96 \\
\times 10^{-10}\end{array}$ & $\begin{array}{l}\text { Excellent barrier to water } \\
\text { vapour, gases, fatty } \\
\text { and oily products }\end{array}$ & $\begin{array}{l}\text { Produces toxic } \\
\text { compounds } \\
\text { when incinerated }\end{array}$ & Chesses, MAP \\
\hline $\begin{array}{l}\text { Cellophane, } \\
\text { nitrocellulose } \\
\text { coated }\end{array}$ & 4.7 & $\begin{array}{l}1.76 \\
\times 10^{-11}\end{array}$ & $\begin{array}{l}1.76 \\
\times 10^{-11}\end{array}$ & $\begin{array}{l}1.76 \\
\times 10^{-11}\end{array}$ & $\begin{array}{l}\text { Excellent clarity and } \\
\text { sparkle, can be used in } \\
\text { coatings and laminations }\end{array}$ & $\begin{array}{l}\text { Not strong for } \\
\text { heavy products }\end{array}$ & Cheeses \\
\hline \multicolumn{8}{|l|}{ Plastic } \\
\hline $\begin{array}{l}\text { Low-density } \\
\text { Polyethylene, } \\
\text { PE-LD }\end{array}$ & 20.2 & $\begin{array}{l}7.17 \\
\times 10^{-9}\end{array}$ & $\begin{array}{l}7.17 \\
\times 10^{-9}\end{array}$ & $\begin{array}{l}2.85 \\
\times 10^{-9}\end{array}$ & $\begin{array}{l}\text { Very flexible, highly } \\
\text { resistant to most solvents, } \\
\text { good moisture barrier }\end{array}$ & $\begin{array}{l}\text { Useless for rigid } \\
\text { containers, poor } \\
\text { barrier for gases }\end{array}$ & $\begin{array}{l}\text { Liquid milk } \\
\text { (pillow packs), } \\
\text { condensed } \\
\text { milk (squeeze } \\
\text { bottles) }\end{array}$ \\
\hline $\begin{array}{l}\text { High-density } \\
\text { Polyethylene, } \\
\text { PE-HD }\end{array}$ & 4.7 & $\begin{array}{l}1.79 \\
\times 10^{-9}\end{array}$ & $\begin{array}{l}1.79 \\
\times 10^{-9}\end{array}$ & $\begin{array}{l}8.15 \\
\times 10^{-9}\end{array}$ & $\begin{array}{l}\text { Moderately flexible, stiffer, } \\
\text { tasteless, odourless }\end{array}$ & $\begin{array}{l}\text { Poor barrier for oxygen } \\
\text { and other gases, } \\
\text { softness, low softening } \\
\text { point, poor clarity }\end{array}$ & $\begin{array}{l}\text { Milk, yogurt, } \\
\text { sour cream, } \\
\text { ice cream }\end{array}$ \\
\hline $\begin{array}{l}\text { Polyvinyl chloride, } \\
\text { PVC }\end{array}$ & 62.0 & $\begin{array}{l}2.44 \\
\times 10^{-9}\end{array}$ & $\begin{array}{l}2.44 \\
\times 10^{-9}\end{array}$ & - & $\begin{array}{l}\text { Versatile material, } \\
\text { compounded with a wide } \\
\text { range of additives (plasticized) }\end{array}$ & $\begin{array}{l}\text { Difficult to recycle, } \\
\text { poor moisture } \\
\text { barrier properties }\end{array}$ & $\begin{array}{l}\text { Cheese, } \\
\text { yogurt, MAP }\end{array}$ \\
\hline $\begin{array}{l}\text { Polyethylene, } \\
\text { Terephthalate, } \\
\text { PET }\end{array}$ & Low & Low & Low & Low & $\begin{array}{l}\text { High tensile strength, low gas } \\
\text { and moisture permeability, } \\
\text { high use-temperature } \\
\text { range, high scuff resistance, } \\
\text { excellent oil barrier }\end{array}$ & Lack of heat sealability & Milk \\
\hline \multicolumn{8}{|l|}{ Paper } \\
\hline Laminatedpapers & Low & Low & Low & Low & $\begin{array}{l}\text { Laminated to aluminium foil } \\
\text { and extrusion coated with } \\
\text { PE offers barrier to moisture, } \\
\text { flavour, and UV light }\end{array}$ & Poor barrier for gases & Butter \\
\hline $\begin{array}{l}\text { Coextrude- } \\
\text { dlaminated } \\
\text { (aseptic) }\end{array}$ & Low & Low & Low & Low & $\begin{array}{l}\text { Barrier against moisture, gas, } \\
\text { odour, light, and UV light }\end{array}$ & Cost & $\begin{array}{l}\text { Milk, milk } \\
\text { powder, yogurt }\end{array}$ \\
\hline Waxed papers & High & Low & Low & Low & $\begin{array}{l}\text { Moisture barrier, low cost, } \\
\text { good resistance, good heat- } \\
\text { sealing characteristics }\end{array}$ & Difficult to keep folded & $\begin{array}{l}\text { Tubs for ice } \\
\text { cream or } \\
\text { cream, butter }\end{array}$ \\
\hline
\end{tabular}




\section{Novel trends in dairy products packaging}

\section{Modified atmosphere packaging (MAP)}

Even though in the past decades MAP was already often used for different food products like fruits or vegetables, meat, fish and bakery products, it is still classified as novel method in packaging of milk and dairy products. It belongs to a group of flexible packaging methods and is generated by altering the initial gaseous environment in the immediate vicinity of the products, whereby no further control during the storage period is performed. Modification of internal atmosphere is achieved by combining three main gases, carbon dioxide $\left(\mathrm{CO}_{2}\right)$, nitrogen $\left(\mathrm{N}_{2}\right)$ and oxygen $\left(\mathrm{O}_{2}\right)$. It aims to slow down deteriorative reactions (chemical and biochemical) and to inhibit / or slow down the growth of spoilage microorganisms (Mullan and McDowell, 2003; Robertson, 2016). This approach allows to pack dairy with none/ or less preservatives and therefore it became a popular solution for minimally processed foods which are increasingly being required by the modern consumers. $\mathrm{CO}_{2}$ was shown to be sufficiently used by injection technique in milk and milk products as shown by Singh et al. (2012). $\mathrm{CO}_{2}$ can easily be added and removed from dairy products with no deleterious effects making it a unique natural antimicrobial and processing agent. The direct addition of $\mathrm{CO}_{2}$ to dairy products coupled with increasing the barrier properties of the containers has been commercially successful and economically feasible with cottage cheese and other fluid products with a shelf life increase of 200-400 \%.

When considering MAP application, permeability to $\mathrm{O}_{2}, \mathrm{CO}_{2}$ and water vapour transmission rates for packaging films are among the most essential factors in determining the package atmosphere composition, which may influence the product's deterioration rate (Church, 1994; Mullan and McDowell, 2003). The atmosphere inside a package can be modified by either passive or active methods. In passive MAP, the rate of change and the final gas composition in the package depend on both the packed product and the permeability of the packaging material. The main disadvantage of passive MAP is that that it may require a long stor- age period to achieve the optimal gas composition, which could be especially important for products with relatively short shelf life. That disadvantage can be overcome with the use of active modification of the atmosphere. Thus, active MAP is usually accomplished by first creating a vacuum and then injecting the desired gas mixture in the package. If packaging material that is used provides adequate barrier with no leakage, the desired atmosphere is directly achieved at the beginning of storage and remains unchanged. The disadvantage of active MAP over passive MAP is the higher cost in equipment and gases (Rodriguez-Aguilera and Oliveira, 2009). Regardless of the chosen pattern it was demonstrated that MAP dramatically extends the shelf life of packaged food products, and in some cases, food does not require any further treatments or any special care during distribution. Various studies have confirmed that MAP is very efficient in controlling mould development, aflatoxin activity, and shelf life extension of various cheese types (Dermiki et al., 2008; Gün et al., 2009; Khoshgozaran et al., 2012; Jalilzadeh et al., 2015). MAP design is composed of handpicking the film type and size of packaging for each product (Farber et al., 2003) so different types of packaging concepts are required for various types of cheeses. According to the available literature data, $\mathrm{CO}_{2}$ concentrations between 20 and $60 \%$ are required to inhibit aerobic microbes which are largely responsible for spoilage of unripened soft cheeses. In addition, in whey cheeses it was shown that MAP atmospheres consisting of 30/70, 40/60 and $60 / 40 \mathrm{CO}_{2} / \mathrm{N}_{2}$ had significant inhibitory effect on the studied spoilage microbes with no influence on sensory characteristics of the product (Papaioannou et al., 2007; Dermiki et al., 2008; Del Nobile et al., 2009; Temiz et al., 2009). Similarly, it was found that for acid coagulated fresh cheeses like cottage cheese or locally present cheese types (i.e. Apulian fresh cheeses Giuncatta and Primosale, Cameros) the best atmospheres were $\geq 75 \% \mathrm{CO}_{2}$, $50 / 50$ or $30 / 70 \mathrm{CO}_{2} / \mathrm{N}_{2}$ (Pintado and Malcata, 2000; Olarte et al., 2001; Esmer et al., 2009). Even though in the case of semi-hard and hard cheese, it is preferable to avoid slicing, even if MAP is shown to provide adequate protection preserving the freshness and good cheese quality through the storage period (Colchin et al., 2001; Favati 
et al., 2007; Rodriguez-Aguiler and Oliveira, 2009; Khoshgozaran et al., 2012). In conclusion, although MAP technology was demonstrated to be effective in prolonging the shelf life of cheeses, it must be noted that the choice of gas mixtures strongly depend on several parameters, especially cheese type, production process, packaging materials etc.

TABLE 2. Evolution of $\mathrm{N}_{2}, \mathrm{O}_{2}$, and $\mathrm{CO}_{2}$ over the storage period (Adopted from: Khoshgozaran et al., 2012)

\begin{tabular}{|c|c|c|c|c|c|}
\hline \multirow[t]{2}{*}{ Cheese type } & \multirow[t]{2}{*}{ MAP (\%) } & \multicolumn{3}{|l|}{ Change observed } & \multirow[t]{2}{*}{ Reference } \\
\hline & & $\mathrm{O}_{2}$ & $\mathrm{CO}_{2}$ & $\mathrm{~N}_{2}$ & \\
\hline $\begin{array}{l}\text { San Simon da } \\
\text { Costa (smoked } \\
\text { semi-hard cow's } \\
\text { milk cheeses) }\end{array}$ & $\begin{array}{l}\text { VP, } 100 \mathrm{~N}_{2}, \\
20 \mathrm{CO}_{2} / 80 \mathrm{~N}_{2} \\
\text { and } 50 \mathrm{CO}_{2} / 50 \mathrm{~N}_{2}\end{array}$ & Constant & $\begin{array}{l}\text { Increase } \\
\left(\text { in } 100 \mathrm{~N}_{2}, 20\right. \\
\left.\mathrm{CO}_{2} / 80 \mathrm{~N}_{2}\right) \text { and } \\
\text { decrease } \\
\left(\text { in } 50 \mathrm{CO}_{2} / 50 \mathrm{~N}_{2} \text { ) }\right.\end{array}$ & NA & $\begin{array}{l}\text { Garabal et } \\
\text { al., (2010) }\end{array}$ \\
\hline $\begin{array}{l}\text { Mozzarella } \\
\text { (soft cheese) }\end{array}$ & $\begin{array}{l}100 \mathrm{~N}_{2}, 10 \mathrm{CO}_{2} / 90 \mathrm{~N}_{2} \\
25 \mathrm{CO}_{2} / 75 \mathrm{~N}_{2} \text { and } 50 \\
\mathrm{CO}_{2} / 50 \mathrm{~N}_{2}\end{array}$ & $\begin{array}{l}\text { Decrease, except } \\
\text { for air which had } \\
\text { increase }\end{array}$ & Increase & Decrease & $\begin{array}{l}\text { Eliot et al., } \\
\text { (1998) }\end{array}$ \\
\hline $\begin{array}{l}\text { Samso Rindless } \\
\text { (semi-hard) }\end{array}$ & $\begin{array}{l}100 \mathrm{~N}_{2}, 20 \mathrm{CO}_{2} / 80 \mathrm{~N}_{2} \\
\text { and } 100 \mathrm{CO}_{2}\end{array}$ & Decrease & Increase & NA & $\begin{array}{l}\text { Juric et al., } \\
(2003)\end{array}$ \\
\hline Cottage & $\begin{array}{l}\text { Air, } 100 \mathrm{CO}_{2}, 75 \mathrm{CO}_{2} / \\
25 \mathrm{~N}_{2} \text {, and } 100 \mathrm{~N}_{2}\end{array}$ & NA & Constant & Constant & $\begin{array}{l}\text { Maniar et al., } \\
\text { (1994) }\end{array}$ \\
\hline $\begin{array}{l}\text { Graviera } \\
\text { (hard cheese) }\end{array}$ & $\begin{array}{l}100 \mathrm{CO}_{2}, 50 \mathrm{CO}_{2} / 50 \\
\mathrm{~N}_{2} \text {, and } 100 \mathrm{~N}_{2} \text {, Air }\end{array}$ & Constant & Constant & NA & $\begin{array}{l}\text { Trobetas et } \\
\text { al., (2008) }\end{array}$ \\
\hline $\begin{array}{l}\text { Havarti } \\
\text { (semi-hard) }\end{array}$ & $25 \mathrm{CO}_{2} / 75 \mathrm{~N}_{2}$ & Constant & Constant & NA & $\begin{array}{l}\text { Kristensen } \\
\text { et al., (2000) }\end{array}$ \\
\hline $\begin{array}{l}\text { Requeijão } \\
\text { (soft cheese) }\end{array}$ & $\begin{array}{l}100 \mathrm{CO}_{2} \text { and } 50 \mathrm{CO}_{2} / \\
50 \mathrm{~N}_{2}\end{array}$ & Constant & Constant & NA & $\begin{array}{l}\text { Pintado and } \\
\text { Malcata (2000) }\end{array}$ \\
\hline $\begin{array}{l}\text { Cameros (fresh } \\
\text { goat cheese) }\end{array}$ & $\begin{array}{l}20 \mathrm{CO}_{2} / 80 \mathrm{~N}_{2}, 40 \mathrm{CO}_{2} / \\
60 \mathrm{~N}_{2}, \text { and } 100 \mathrm{CO}_{2}\end{array}$ & Below 2 \% & Decrease & NA & $\begin{array}{l}\text { Olarte et al., } \\
(2002)\end{array}$ \\
\hline $\begin{array}{l}\text { Myzithra Kalathaki } \\
\text { (whey cheese) }\end{array}$ & $\begin{array}{l}20 \mathrm{CO}_{2} / 80 \mathrm{~N}_{2}, 40 \mathrm{CO}_{2} / \\
60 \mathrm{~N}_{2}, \text { and } 60 \mathrm{CO}_{2} / 40 \mathrm{~N}_{2}\end{array}$ & Constant & Decrease & Increase & $\begin{array}{l}\text { Dermiki et } \\
\text { al., (2008) }\end{array}$ \\
\hline Stracciatella & $\begin{array}{l}\text { VP, } 50 \mathrm{CO}_{2} / 50 \mathrm{~N}_{2}, 95 \\
\mathrm{CO}_{2} / 5 \mathrm{~N}_{2}, 75 \mathrm{CO}_{2} / 25 \\
\mathrm{~N}_{2}, \text { and } \\
30 \mathrm{CO}_{2} / 65 \mathrm{~N}_{2} / 5 \mathrm{O}_{2}\end{array}$ & Constant & Constant & Constant & $\begin{array}{l}\text { Gammariello } \\
\text { et al., (2009) }\end{array}$ \\
\hline $\begin{array}{l}\text { Crottin de } \\
\text { Chavignol }\end{array}$ & $\begin{array}{l}\text { Air, VP and } \\
50 \mathrm{CO}_{2} / 50 \mathrm{~N}_{2}\end{array}$ & Increase & Decrease & NA & $\begin{array}{l}\text { Esmer et al., } \\
(2009)\end{array}$ \\
\hline $\begin{array}{l}\text { Surface mould- } \\
\text { ripened }\end{array}$ & $\begin{array}{l}0 \mathrm{O}_{2} / 27 \pm 6 \mathrm{CO}_{2} \text { and } \\
2 \pm 1 \mathrm{O}_{2} / 19 \pm 2 \mathrm{CO}_{2}\end{array}$ & Decrease & Increase & NA & $\begin{array}{l}\text { Rodriguez- } \\
\text { Aguilera } \\
\text { et al., (2011) }\end{array}$ \\
\hline
\end{tabular}

\section{Edible coatings and films}

Edible films and coatings become very interesting concept not only because of their benefits on food product but also in novel product differentia- tion and its launching on the market. Coatings are aimed to have similar functions as those of conventional packaging with great ability to act, as barriers to water vapour, gases, and flavour compounds. What is also very important in providing good shelf 
life stability is that they can improve structural integrity and mechanical-handling of coated foods. However, their main disadvantage is that they cannot be used as the only packaging, in other words secondary non-edible packaging is required in order to properly and hygienically handle packed foodstuff. Besides mentioned, they are often used as carriers of different active compounds that can act as antimicrobials, antioxidants or nutraceuticals (Rodriguez-Aguiler and Oliveira, 2009). These properties will be covered later in the article. Being isolated from natural sources edible coatings can be classified according to their main structuring molecules to protein based, polysaccharide based, resins and lipid based used alone or together. The addition of plasticizers or/and surfactants is often required (Falguera et al., 2011). Within dairy products, edible packaging materials are mostly used for cheese (Table 2). Besides, providing better quality and preserving freshness, edible packaging could significantly reduce the final costs of cheese packaging by reducing the amount of usually required packaging material. However, it is important to note that the applied coatings need to be neutral considering sensory characteristics as they could influence/or interfere with sensory properties characteristics of the packaged cheese (Karaman et al., 2015). In the group of polysaccharides, galactomannan and chitosan were used as cheese coatings. Cerquirerea et al., (2009) tested their application on semi-hard cheeses. Authors found that galactomannan coatings significantly reduced respiration rates and mould growth on the cheese surface that was significant in uncoated cheese samples.

In general, protein-based films have more interesting mechanical and barrier properties than those consisting of polysaccharides. Many protein materials such as collagen, corn zein, wheat gluten, soy protein isolate, fish proteins, ovalbumin, whey protein isolate and casein have been tested. Milk proteins, like casein, become very interesting not only because of their good properties but also because of their industrial surplus (Khwaldia et al., 2004). Proteins isolated from milk have great nutritional value, but also, they have some useful physical characteristics like solubility in water and emulsifying properties that makes them great choice as edible coating.

\section{Application of nanocomposites}

Nanotechnology implies the use of materials on a nanometric scale, between $1 \mathrm{~nm}$ and $100 \mathrm{~nm}$ in size (Duncan, 2011). Nanoparticles are aimed to improve some properties of existing packaging materials such as mechanical, thermal and barrier properties (O' Callaghan and Karry, 2016).

Nanoparticles are frequently used in active realising systems. They can be carrier of antibacterial compounds that are then immobilized in the polymer matrix and coated on the product surface. Controlling storage conditions, triggered release of active agents occur (Ruparelia et al., 2008). The potential application for a given nanoparticle depends on many factors like the material type (Ren et al., 2009), the particle shape (Wang et al., 2005) and the applied concentration (Kim et al., 2003). For example, Carbone et al., (2016) reported, that silver montmorillonite (Ag-MMT) nanoparticles, which were obtained by replacing $\mathrm{Na}^{+}$ions naturally present in montmorillonite with $\mathrm{Ag}^{+}$ions, were embedded into an agar based matrix in order to prolong the shelf life of Fior di Latte cheese. Even though metal-based nanoparticles (ex. silver containing) have shown great antibacterial activity such systems might be unacceptable from a commercial point of view because their effects on human health and the environment on long term has not been clarified so far. For this reason packaging systems containing food grade nanoparticles may be more desirable, such as sorbic acid that is legally accepted and food grade antimicrobial (Cruz-Romero et al., 2013).

In the dairy sector, one of most frequently used properties of nanotechnology is enhancement of oxygen barrier properties of nanolaminates, nanocomposite bottles and bins with silver nanoparticles (Gopirajah and Anandharamakrishnan, 2017). Nanoclays and nanocrystals embedded in the plastic films and bottles are shown to block oxygen, carbon dioxide and moisture transfer thus avoiding them to reach packed food products (milk and dairy products). The advantage of clay nanocomposite in the packaging material is that it offers better shelf life, shutter proof, these materials are lighter in weight and heat resistant (Ravichandran, 2010).

This feat was achieved by incorporating silver-based microparticles with bactericidal, antimi- 
crobial and self-sterilizing properties into the rigid plastic bottles used as packaging for the milk. The microparticles are included as a powder in the polyethylene preform that is used to make plastic bottles by blow or injection moulding. The microparticles are inert, so there is no risk of their detaching from the packaging and coming into contact with the milk (Anonymous 1).

Furthermore, in the domain of smart packaging, plastic materials with incorporated nanosensors are aimed to detect off-flavours and gases produced by food item when it spoils and the packaging itself changes colour to emit an alert (Mehar Afroz et al., 2012).

\section{Smart/intelligent and active packaging}

By a definition, smart packaging systems are used as non-traditional packaging with special functions generating enhanced product that result in safer, more nutritious or appealing food products, whilst being environmentally friendly. They can also be informative yielding to improved logistical efficiency and optimised product recall. In addition, smart packaging technologies can be further optimised by the incorporation of nanotechnology, which can be utilised actively or intelligently, to enhance or to extend package function.

Intelligent packaging contains a device, positioned internally or externally to the package that can monitor the condition of the product, package or packaging environment. The device can provide information on these aspects, but does not alter the condition of the package or product (O'Callaghan and Kerry 2016). Mostly used in dairy packaging are time-temperature indicators and indicators of ripening that will be detailed in following subsections.

Active packaging can be regarded as a subset of smart packaging and refers to incorporation of certain active components into packaging film or within packaging containers with the aim of maintaining and extending product shelf life, but also to improve the safety of the packaged product. Thus, active packaging includes components of packaging systems that are for example capable of scavenging oxygen, absorbing carbon dioxide, moisture and/or flavour/odour taints; releasing carbon dioxide, ethanol, antioxidants and/or other preservatives; maintaining temperature control and/or compensating temperature changes (Conte et al., 2013).

Since antimicrobial group was the most frequently studied in the past decade, examples will be given in next subsection.

Commonly used and commercialised type of active packaging applied on cheese belong to group of ethanol vapour generators and desicant-containing pouches for moisture control (Biji et al., 2015). Another group belongs to enzyme based systems that offer an alternative method to produce lactose-free fluid milk products (Vermeiren et al., 1999; Fernández et al., 2008). Immobilized enzymes are aimed to reduce negative sensory characteristics of batch processing (Goddard et al., 2007; Mahoney et al., 2013). For example, lactase can be covalently immobilized onto UV functionalized low-density polyethylene (PE-LD) surface made between layers of repeated depositions of polyethylenimine (PEI) and glutaraldehyde (GL) cross-linking layers (Wong and Goddard, 2014). Presence of lactase results in decrease in lactose content of milk that is of great importance for consumers suffering from lactase deficiency (Goddard et al., 2007). Even in wet conditions, immobilized lactase in biofilm could retain up to $64 \%$ of its activity (Wong and Goddard, 2014). Detailed studies on relationship between product quality, consistency, and consumer acceptance with bacterial counts, sensory acceptance, and shelf life of the final product are done for fluid milk (Hansen and Arora, 1990; Grosová et al., 2008; Martin et al., 2012). UHT sterilised milk can often be characterised by "cooked" and "stale" flavour resulting from protein changes during thermal processing. Zabbia et al., (2009) showed how protein loaded film incorporated into the UHT brick packaging can decrease the concentration of compounds baring those flavours. Perkins at al., (2007) investigated the addition of oxygen-scavenging film into commercially used aseptic pouches and observed significant decrease in dissolved oxygen concentration as well as in some stale flavour volatiles. Johnson et al., (2015) tested the efficiency of titanium dioxide $\left(\mathrm{TiO}_{2}\right)$ addition to high-density polyethylene (PE-HD) packages in order to reduce light induced oxidation of 
extended shelf life milk ( $2 \%$ total fat). Authors found that levels of incorporated $\mathrm{TiO}_{2}$ above $1.3 \%$ may effectively protect milk quality (measured by sensory evaluation, analysis of changes in volatile compounds, thiobarbituric reactive substances and riboflavin concentration) during an extended period of retail lighting exposure. A Swedish producer Ecolean ${ }^{\oplus}$ developed a combined packaging film made of $40 \%$ calcium carbonate (chalk) blended with conventional PP and PE for production of special pouches. Using chalk provides added stiffness and whiteness, reduces weight of the package, and is a good gas and light barrier. Thus, possibility of oxidative degradation is put down to minimum and such pouches are shown to extent milk shelf life up to six-month even if kept unrefrigerated (Anonymous 2). Moraes et al., (2007) found that packaging containing antimicrobial components prevented butter spoilage. Gomes et al., (2009) found that the application of convenient oxygen scavengers could extend shelf life of cheese spread. When it comes to packing of dairy with probiotic bacteria as living products, it is of great importance to assure their viability all through packaging process and storing period until final consummation. In order to ensure it, several methods might be combined, such as use of combining multi-layered plastic material with incorporated oxygen absorbent, microencapsulation of probiotic strains, addition of carbon dioxide and storage at low temperatures (Lopez-Rubio et al., 2004; Rathore et al., 2013; Dobrucka and Cierpiszewski, 2014; Tripathi et al., 2014, Ramos et al., 2015). Cruz et al., (2013) tested the effect of the glucose oxidase added into yogurt containing probiotic bacteria and stored in different packaging materials. Authors found that samples packed in plastic containers with reduced permeability had more than satisfactory viability of probiotic bacteria and the desired overall quality of packed yogurt. In addition, results of several studies confirmed that multi-layered materials like NUPAK containers (combination of high-impact polystyrene (HIPS), ethylene-vinyl alcohol copolymer (EVOH) and PE), with oxygen absorbers provide the best protection for probiotic foods (Miller et al., 2003 a, b; Talwalkar et al., 2004; Kudelka, 2005).

Indeed, active technologies offer the ability to achieve a desired technical effect on packed dairy. However, most of literature data typically do not evaluate the potential for unanticipated adverse effects on dairy quality.

\section{Antimicrobial packaging}

Antimicrobial packaging has gained increased attention especially in cheese packaging since it usually includes combination of an edible film or coating and an antimicrobial component. A conventional multilayer film exhibiting antimicrobial features usually includes four layers namely the control layer, matrix layer, barrier layer, and outer layer. In such structure, into the matrix layer, an antimicrobial substance would be imbedded. By the control layer adjacent to the matrix layer, aims to control the release of antimicrobial substance to the food surface. Nonedible antimicrobial films applied as active packages are classified into two groups - (1) antimicrobial containing films in which the antimicrobial agents migrate to the food surface and (2) those with an antimicrobial agent, bounding to the film surface layer. Complete or partial losing of antimicrobial activity of the applied active agent during film production and storage is one of the main drawbacks of antimicrobial films. Chemical preservatives that can be used in active antimicrobial-releasing systems include organic acids and their salts (primarily sorbates, benzoates, and propionates), parabens, sulphites, nitrites, chlorides, phosphates, epoxides, alcohols, ozone, hydrogen peroxide, diethyl pyrocarbonate, and bacteriocins (Pocas and Pintado, 2010; Biji et. al, 2015). However, with aims to protect human's health and to produce chemical free foodstuff, their use is under the loop. One of the most used antimicrobials is lysozyme, which is an enzyme showing great activity against both gram-positive and gram-negative bacteria. In the dairy industry, it is commercially used for the preservation of cheese and for the prevention of holes formation in those cheese types where it is undesired property (McSweeney, 2007). Sinigaglia et al., (2008) incorporated lysozyme and Na-ethylenediaminetetraacetic acid (EDTA) into the typical conditioning brine of the cheese. According to the obtained results, the used combination of antimicrobial components significantly inhibited the growth of coliforms and Pseudomonadaceae during the first 7 days of storage at $4{ }^{\circ} \mathrm{C}$ and thus, proved to be effective in prolonging shelf life of traditional Mozzarella cheese. 
Nisin, polycyclic peptide produced by the bacterium Lactococcus lactis has shown antibacterial activity against large spectrum of Gram-positive and Gram-negative bacteria, particularly against pathogens like Listeria monocytogenes, Brochothrix thermosphacta, Micrococcus flavus, Lactobacillus helveticus, and Pediococcus pentosaceus (Lee et al., 2004; Sobrino-Lopez and Martín-Belloso, 2008). As a surface-active molecule, nisin is able to bind to various compounds and it is therefore convenient to be sorbed on solid surfaces and is aimed to destroy the adhering bacterial cells. There are also some works showing its reliable application in cheese packaging (Sobrino-Lopez and Martín-Belloso, 2008; Jin et al., 2009; Hoang et al., 2010; Irkin and Esmer, 2015). For example, Hanusova et al., (2010) showed that PE films incorporated with nisin significantly improved shelf life of soft unripened cheese. Hoang et al., (2010) and Martins et al., (2010) found that the application of edible films containing nisin were highly efficient for packaging of semi hard Babybell cheese and Ricotta cheese preventing the growth of Listeria innocua and Lysteria monocytogenes, respectively.

Lee et al., (2003) showed that a 3-mm-thick nisin and a-tocopherol in paper used as $3 \%$ coating had antioxidative (lipid oxidation) and antimicrobial (against M. flavus) effect on milk cream. Accordingly, the proposed packaging showed to be suitable for creating an antimicrobial and/or antioxidative feature against $M$. flavus and/or lipid oxidation in the milk cream, respectively (Haghighi-Manesh et al., 2017). Jin (2010) tested the effect of packaging skim milk into bottles coated with nisin and polylactic acid (PLA). According to the observed results such type of active packaging could be useful in protecting skim milk from L. moncytogenes contamination. Natamycin (or pimaricin) is another antifungal antibiotic produced by Streptomyces natalensis, and is commonly used to control fungus growth on the cheese surface (Dalhoff and Levy, 2015). It must be used at concentrations between 1 and 20 ppm, since yeasts are generally less resistant (min. inhibitory concentration below 5 ppm) than moulds (min. inhibitory concentration above 10 ppm). As an antimycotic substance applied for surface-treatment of hard, semi-hard and semisoft cheeses, it is commercially permitted in 32 countries (Jalillazdeh et al., 2015). Kallinteri et al., (2013) observed that natamycin, added either solely or combined with nisin, efficiently suppressed fungal growth in the Galotyri cheese. Santonicola et al., (2017) showed that chitosan enriched with natamycin significantly reduced yeasts and moulds in cheese stored at $20{ }^{\circ} \mathrm{C}$ for 7 days. In addition, chitosan had better effect than methylcellulose that was also tested in the same study.

Because of its antimicrobial nature as polymer itself, chitosan can also be used as active agent by its own, without addition of other antimicrobial compounds (when it serves as carrier). Various studies have shown it positive effect in prolonging shelf life of packed cheese (Moreira et al., 2011; Costa et al., 2018). Structurally, chitosan is a chitin deacetylated derivative and the second most copious polysaccharide in nature found to be biofunctional, biodegradable, biocompatible, nontoxic, and with strong antimicrobial features. However, due to its poor mechanical properties as well as poor solubility at high $\mathrm{pH}$ values, it would be more reasonable for coating on plastic film packaging in medium acid foods (Dutta et al., 2009; Kanatt et al., 2012; Haghighi-Manesh et al., 2017). It is also important to mention that some precautions should be taken when using it on dairy since it is soluble only in acidic $\mathrm{pH}$ and sometimes may impact the product original colour.

Taking into account chemically free, eco and green concept it is common to use natural plant and essential oils extract as natural preservatives to increase dairy shelf life. Extracts are generally prepared from cinnamon, thyme, bergamont oils etc. with their isolates as cinnamaldehyde, carvacrol, linalool, sabinene, thymol, eugenol, menthol, camphene and have shown great antimicrobial and fungiostatic activity (Brasil et al., 2012; Sanla-Ead et al., 2012; dos Santos Gouvea et al., 2017). Up to date focus was made on cinnamaldehyde incorporated in various systems (coatings, films, or nanoparticles) and different carrier matrixes such as pectin (Brasil et al., 2012; Ravishankar et al., 2012), starch (Arfa et al., 2007; Kechichian et al., 2010), chitosan (Brasil et al., 2012; Ouattara et al., 2000), wax paraffin (Rodriguez-Lafuente et al., 2010), polypropylene, polyethylene/ethylene vinyl alcohol copolymer (Lopez et al., 2007), cellulose (Sanla-Ead et al., 2012), and soy protein (Arfa et al., 2007; Gamage et al., 2009). Kavas and Kavas 
(2016) studied the effect of egg white based coating fortified with sage or lemon balm essential oils at various concentrations on Turkish cheese type Lor. Authors found that sage oil had much better antibacterial properties, while lemon balm essential oil exerted stronger antifungal action. Moro et al., (2013) evaluated the use of 12 essential oils obtained from certain aromatic plants as natural cheese covers in order to prevent the growth of $P$. verrucosum - one of common cheese contaminants. The most effective essential oils were obtained from Anethum graveolens, Hyssopus officinalis and Chamaemelum nobile resulting in $50 \%$ inhibition of fungal growth at concentrations lower than $0.02 \mu \mathrm{L}$ $\mathrm{mL}^{-1}$.

TABLE 3. Examples of edible and antimicrobial packaging applied in various cheese types (Adopted from da Silva Ramos et al., 2015)

\begin{tabular}{|c|c|c|c|c|}
\hline $\begin{array}{l}\text { Bioactive } \\
\text { component }\end{array}$ & $\begin{array}{l}\text { Film/Coating } \\
\text { type }\end{array}$ & Cheese type & Observations & Reference \\
\hline Lysozyme & Chitosan & Mozarella & Decrease in microbial contamination & Duan et al., (2007) \\
\hline Lysozyme & Zein & Kashar & $\begin{array}{l}\text { Increase L.monocytogenes } \\
\text { counts in cheese for } 8 \text { weeks } \\
\text { at } 4^{\circ} \mathrm{C} \text { was prevented }\end{array}$ & Ünalan et al., (2013) \\
\hline Natamycin & Chitosan & $\begin{array}{l}\text { Semi-hard } \\
\text { regional cheese }\end{array}$ & Decrease in moulds and yeasts & Fajardo et al., (2010) \\
\hline \multirow[t]{2}{*}{$\begin{array}{l}\text { Natamycin, } \\
\text { Nisin }\end{array}$} & Cellulose & $\begin{array}{l}\text { Sliced } \\
\text { Mozzarella }\end{array}$ & $\begin{array}{l}\text { Inhibition of fungal } \\
\text { growth }\end{array}$ & Dos Santos Pires et al., (2008) \\
\hline & Tapioca starch & Port Salut & $\begin{array}{l}\text { Decrease in L. innocua and } \\
\text { S. cerevisiae counts }\end{array}$ & Ollé Resa et al., (2014) \\
\hline $\begin{array}{l}\text { Linalool, } \\
\text { carvacrol, } \\
\text { thymol }\end{array}$ & Starch & Cheddar & $\begin{array}{l}\text { Reduction in A. niger counts after } \\
35 \text { days of storage at } 15^{\circ} \mathrm{C}\end{array}$ & Kurowel et al., (2014) \\
\hline $\begin{array}{l}\text { Olive leaf } \\
\text { extract }\end{array}$ & Methylcellulose & Kasar & $\begin{array}{l}\text { Decrease in S. aureus counts } \\
\text { after } 7 \text { and } 14 \text { days of storage }\end{array}$ & Ayana and Turhan (2009) \\
\hline \multirow[t]{2}{*}{ Chitosan } & Na-caseinate & Cheddar & $\begin{array}{l}\text { Significant reduction in } \\
\text { mesophyllic and psychrotrophic } \\
\text { bacteria and yeasts counts }\end{array}$ & Moreira et al., (2011) \\
\hline & $\begin{array}{l}\text { Chitosan/ } \\
\text { whey protein }\end{array}$ & Ricotta & $\begin{array}{l}\text { Significant reduction in mesophyllic } \\
\text { and psychrotrophic bacteria }\end{array}$ & Di Pierro et al., (2011) \\
\hline
\end{tabular}

\section{Time temperature indicators (TTIS)}

TTIs are tools designed for continuously monitoring the temperature in refrigerated and frozen product along the distribution chain. TTIs are today the most common commercial systems used in packaging, since they are simple and their response do not depend on the nature of the food or the concentration of chemical substances but on the temperature variations. They offer visual changes that are accelerated with increasing temperature based on physical $\left(3 M^{\mathrm{TM}}\right.$ MonitorMark $\left.{ }^{\mathrm{TM}}\right)$, chemical (Keep-it ${ }^{\oplus}$, Fresh-
Check $^{\oplus}, \mathrm{OnVu}^{\oplus}$, FreshCode ${ }^{\oplus}$ ), enzymatic $\left(\mathrm{VITSAB}^{\oplus}\right)$ or microbiological processes. Some systems are oriented to consumers, giving in a simple way the appropriate information. This includes barcodes that disappear upon the change, labels that advance in the stick or indicators sited next to a reference to follow colour change to the naked eye.

\section{Freshness and ripening indicators}

Freshness indicators monitor the quality of packed foods by reacting in one way or another 
to metabolites generated in the fresh food product as a result of microbial growth or metabolism (Realini and Marcos, 2014). Changes in the concentration of metabolites such as glucose, organic acids (e.g. I-lactic acid), ethanol, carbon dioxide, biogenic amines, volatile nitrogen compounds or sulphur derivatives during storage indicate microbial growth and therefore open the possibility of using their presence as freshness indicators (Arvanitoyannis and Stratakos, 2012). In the case of dairy products, especially cheese varieties undergoing intensive ripening processes such indicators might be of a great importance in monitoring the occurrence of excessive formation of biogenic amines. Smart packaging with systems that monitor food freshness through the detection of these metabolites has been described, however in most cases successful commercialization is still rare (Romero et al., 2017).

\section{Biodegradable packaging}

One challenge facing the food packaging industry is the efforts given to produce biobased - primary packaging that is at the same time biodegradable but also that matches the durability of the packaging with product shelf life. The biggest issue is how to make the biologically based packaging material, that by its nature is aimed to degrade naturally during certain period, but in this case, it must remain stable without changes of mechanical and/ or barrier properties and must function properly during storage until disposal. Subsequently, the material should biodegrade efficiently after discarding (Petersen et al., 1999).

The most used material in this group is polylactic acid (PLA) that is currently used for production of different packaging shapes (cups, bowls, foils, and food storage containers). Foamed PLA is used as an insulator and is an alternative to foamed polystyrene (PS). PLA have good mechanical properties, similar to poly(ethylene terephthalate), (PET), and polypropylene (PP). Additionally, an important component is the plasticizer, which enhances flexibility and extensibility. In general, these coatings exhibit higher water permeability, lower oxygen permeability, and inferior mechanical properties compared with traditional packaging (McHugh and Krochta, 1994). The influence of the packag- ing with biodegradable PLA and PLA coated with a barrier of pure silicon oxide and in combination with modified atmosphere (MAP) on the shelf life of soft cheese Kleo produced in Latvia, was studied by Dukalska et al., (2011). Modified atmosphere was made with $30 \%$ carbon dioxide and $70 \%$ nitrogen and the samples were stored at $4{ }^{\circ} \mathrm{C}$ for 32 days. The best results were obtained for cheese packaged with PLA, coated with a barrier of pure silicon oxide and in combination with MAP, observing that, in this case, the cheese quality evaluated through the colour was acceptable and moulds were not observed after 32 days storage. Balaguer et al., (2014) developed gliadin films crosslinked with cinnamaldehyde (5\%) and enriched with natamycin $(0.5 \%)$. Cast films were used to pack slices of soft and semi-hard cheeses extending their shelf life due to fungiostatic action of cinnamaldehyde. Moreover, the greatest effectiveness was observed for soft cheese, probably due to its higher water activity that favoured the release of the active substances. No considerations were performed by the authors in relation to the biodegradability of the matrix developed after crosslinking.

Shelf life of plain yogurt (3.5\% fat) was studied by Frederiksen et al., (2003) for 5 weeks in PLA or PS cups under fluorescent light (3500 lux) or in darkness. Practically, neither oxidation neither changes in vitamin content (riboflavin and $\beta$-carotene) occurred when stored in dark. However, for samples exposed to the light, PLA was shown to be at least as effective as PS in preventing colour changes and lipid oxidation and better in prevention of vitamins. Regarding migration concern, the amount of styrene in yogurt stored in PS cups increased during storage, whereas lactate was not found in yogurts stored in PLA (Gerschenson et al., 2018).

\section{Conclusion}

Packaging methods of the dairy industry are increasingly changing in order to match the needs of consumers and the rest of the food industry. Novel concepts of dairy packaging comprise numerous possibilities that enable not only protection but also the prolongation of shelf life and /or improvement of functional properties of products. Some 
of the most recently introduced methods are that sophisticated to enable the release of information regarding the freshness of the product. Such innovative approaches also enhance the safety and security of dairy product and along with the progress of their commercialization it is almost safe to claim that the number of retailer and consumer complaints will decrease.
Therefore, more studies are needed concerning the use of novel packaging systems as well as processing methods to extend and to enhance food safety. Advanced technology will continue to allow dairy industry to meet consumer needs for food safety, quality, cost, information and environmental concerns with food packaging on the global market.

\section{Novi trendovi pakiranja mlijeka i mliječnih proizvoda}

\section{Sažetak}

Metode pakiranja mliječnih proizvoda neprekidno se razvijaju u skladu s razvojem ambalažnih materijala, te u skladu sa zahtjevima potrošača. Cilj ovog preglednog rada je pružiti uvid u trenutno dostupne nove metode pakiranja mliječnih proizvoda. Pakiranje u modificiranoj atmosferi (MAP) prvenstveno se primjenjuje u sirarstvu. Uporaba jestivih pakiranja značajno je smanjila uobičajeni utrošak ambalažnog materijala za pakiranje sira. Nanomaterijali i aktivno pakiranje mogu se primijeniti u svrhu produljenja roka valjanosti bilo smanjenjem propusnosti materijala ili smanjenjem pojave nepoželjnih senzorskih svojstava mliječnih proizvoda i time utjecati na produljenje njihove kvalitete. U aktivno pakiranje ubrajaju se primjerice izračivači kisika, apsorberi ugljikova dioksida, regulatori vlage/okusa/mirisa, antioksidansi i/ili drugi konzervansi, održavanje nadzora nad temperaturom i/ili kompenziranje temperaturnih promjena, antimikrobno pakiranje, itd. Antimikrobno pakiranje privlači sve više pažnje kako znanstvenika tako i industrije budući da istovremeno omogućava održavanje kvalitete i zdravstvene ispravnosti proizvoda. S ekološkog aspekta najzanimljivijim se smatra pakiranje u biorazgradljivu ambalažu. Glavni izazovi za takve materijale su omogućiti osiguravanje čvrstoće i integriteta pakovine u odnosu na trajnost proizvoda.

\section{Ključne riječi: mliječni proizvodi, MAP, antimikrobno pakiranje, pametno pakiranje, jestiva ambalaža}

\section{References}

1. Alvarez, V., Pascall, M. (2011): Packaging In Encyclopedia of Dairy Sciences, $2^{\text {nd }}$ ed.; (Fuquay, J., Fox, P., McSweeney, P., Eds.), Academic Press, San Diego, CA, USA, 2011, pp 16-23. https://doi.org/10.1016/B978-0-12-374407-4.00387-3

2. Anonymous 1: https://www.nanowerk.com/ nanotechnology-news/newsid=40955.php/ Accesed at 07.03.2018.

3. Anonymous 2: http://blog.drupa.com/de/ecoleanpackaging/ Accesed at 01.02.2018.

4. Arfa, B.A., Preziosi-Belloy, L., Chalier, P., Gontard, N. (2007): Antimicrobial paper based on a soy protein isolate or modified starch coating including carvacrol and cinnamaldehyde. Journal of Agricultural and Food Chemistry 55, 2155-2162. https://doi.org/10.1021/jf0626009
5. Arvanitoyannis, I.S., Stratakos, A.C. (2012): Application of modified atmospherepackaging and active/smart technologies to red meat and poultry: A review. Food and Bioprocess Technology 5 (5), 1423-1446. https://doi.org/10.1007/s11947-012-0803-z

6. Ayana, B., Turhan, K.N. (2009): Use of antimicrobial methylcellulose films to control Staphylococcus aureus during storage of Kasar cheese. Packaging Technology and Science 22 (8), 461-469. https://doi.org/10.1002/pts.870

7. Balaguer, M.P., Fajardo, P., Gartner, H., Gomez-Estaca, J., Gavara, R., Almenar, E., Hernandez-Munoz, P. (2014): Functional properties and antifungal activity of films based on gliadins containing cinnamaldehyde and natamycin. International Journal of Food Microbiology 173 , 62-71. https://doi.org/10.1016/j.ijfoodmicro.2013.12.013 
8. Biji, K.B., Ravishankar, C.N., Mohan, C.O., Srinivasa Gopal, T. K. (2015): Smart packaging systems for food applications: a review. Journal of Food Science and Technology 52 (10), 6125-6135. https://doi.org/10.1007/s13197-015-1766-7

9. Brasil, I., Gomes, C., Puerta-Gomez, A., Castell-Perez, M., Moreira, R. (2012): Polysaccharide-based multilayered antimicrobial edible coating enhances quality of fresh-cut papaya. LWT-Food Science and Technology 47, 39-45. https://doi.org/10.1016/j.lwt.2012.01.005

10. Cao, X.L., Corriveau, J. (2008): Migration of bisphenol A from polycarbonate baby and water bottles into water under severe conditions. Journal of Agricultural and Food Chemistry 56 (15), 6378-6381. https://doi.org/10.1021/jf800870b

11. Carbone, M., Donia, D.T., Sabbatella, G., Antiochia, R. (2016): Silver nanoparticles in polymeric matrices for fresh food packaging. Journal of King Saud University Science 28, 273-279. https://doi.org/10.1016/j.jksus.2016.05.004

12. Cerquirea, M., Lima, A., Vicente, A., Teixeira, J., Moreira, R. (2009): Novel functional polysaccharides as edible coatings for cheese. Journal of Agriculturan and Food Chemistry 57, 1456-1462. https://doi.org/10.1021/jf802726d

13. Church, N. (1994): Developments in modified-atmosphere packaging and related technologies. Trends in Food Science \& Technology 5 (11), 345-352. https://doi.org/10.1016/0924-2244(94)90211-9

14. Ciron, C.I.E., Gee, V.L., Kelly, A.L., Auty, M.A. (2011): Effect of microfluidization of heattreated milk on rheology and sensory properties of reduced fat yoghurt. Food Hydrocolloids 25, 1470-1476. https://doi.org/10.1016/j.foodhyd.2011.02.012

15. Conte, A., Angiolillo, L., Mastromatteo, M., Del Nobile, M.A. (2013): Technological Options of Packaging to Control Food Quality In Agricultural and Biological Sciences "Food Industry" (Muzzalupo, I., ed). pp 355-379. https://doi.org/10.5772/53151

16. Cruz-Romero, M.C., Murphy, T., Morris, M., Cummins, E., Kerry, J.P. (2013): Antimicrobial activity of chitosan, organic acids and nano-sized solubilisates for potential use in smart antimicrobially-active packaging for potential food applications. Food Control 34, 393-397. https://doi.org/10.1016/j.foodcont.2013.04.042

17. Cruz, A.G., Faria, A.F.J., Van Dender, A.F.G. (2007): Packaging system and probiotic dairy foods. Food Research International 40, 951-956. https://doi.org/10.1016/j.foodres.2007.05.003

18. Cruz, A.G., Castro, W.F., Faria, J.A.F., Bolini, H.M.A., Celeghini, R.M.S., Raices, R.S.L., Oliviera, C.A.F.; Freitas, M.Q.; Conte Junior, C.A.; Marsico, E.T. (2013): Stability of probiotic yogurt added with glucose oxidase in plastic materials with different permeability oxygen rates during the refrigerated storage. Food Research International 51, 723-728. https://doi.org/10.1016/j.foodres.2013.01.028

19. Cruz, J.M., Sanches-Silva, A., Sendón-García, R., Franz, R., Paseiro-Cunha, S. C, Almeida C, Mendes, E., Fernandes, J.O. (2011): Simultaneous determination of bisphenol A and bisphenol $B$ in beverages and powdered infant formula by dispersive liquid-liquid micro-extraction and heart-cutting multidimensional gas chromatography-mass spectrometry. Food Addititives and Contaminants Part A 28 (4), 513-526. https://doi.org/10.1080/19440049.2010.542551
20. Da Silva Ramos, O.L., Perreira, R.N.C., Martins, J.T., Malcata, F.X. (2015): Edible Packaging for Dairy Products In Edible Food Packaging - Materials and Processing Technologies (Cerqueira, M.A.P., Pereira, R.N.C., da Silva Ramos, O.L., Teixeira, J.A.C., Vicente, A.A., eds), CRC Press, Talyor \& Francis, pp. 383-412.

21. Dalhoff, A.A.H., Levy, S.B. (2015): Does use of the polyene natamycin as a food preservative jeopardise the clinical efficacy of amphotericin B? A word of concern. International Journal of Antimicrobial Agents 45, 564-567. https://doi.org/10.1016/j.ijantimicag.2015.02.011

22. Del Nobile, M.A., Conte, A., Incoronato, A.L., Panza, O. (2009): Modified atmosphere packaging to improve the microbial stability of Ricotta. African Journal of Microbiology Research 3 (4), 137-142.

23. Dermiki, M., Ntzimani, A., Badeka, A., Savvaidis, I., Kontominas, M. (2008): Shelf-life extension and quality attributes of the whey cheese "Myzithra Kalathaki" using modified atmosphere packaging. LWT Food Science and Technology 41, 284-294. https://doi.org/10.1016/j.lwt.2007.02.014

24. Di Pierro, P., Sorrentino, A., Mariniello, L., Giosafatto, C.V.L., Porta, R. (2011): Chitosan/ whey protein flm as active coating to extend Ricotta cheese shelf-life. LWT - Food Science and Technology 44 (10), 2324-2327. https://doi.org/10.1016/j.lwt.2010.11.031

25. Dobrucka, R., Cierpiszewski, R. (2014): Active and Intelligent Packaging Food - Research and Development A Review. Polish Journal of Food and Nutrition Sciences 64 (1), 7-15. https://doi.org/10.2478/v10222-012-0091-3

26. Dos Santos Gouvea, F., Rosenthal, A., Da Rocha Ferreira, E.H. (2017): Plant extract and essential oils added as antimicrobials to cheeses: a review. Ciência Rural, Santa Maria 47 (08) 1-9.

27. Dos Santos Pires, A., Soares, N., Andrade, N., Silva, L., Camilloto, G. Bernardes, P. (2008): Development and evaluation of active packaging for sliced Mozzarella preservation. Packaging Technology and Science 32, 375-383. https://doi.org/10.1002/pts.815

28. Duan, J., Park, S., Daeschel, M., Zhao, Y. (2007): Antimicrobial chitosan-lysozyme (CL) films and coatings for enhancing microbial safety of mozzarella cheese. Journal of Food Science 72, 355-362. https://doi.org/10.1111/j.1750-3841.2007.00556.x

29. Dukalska, L., Muizniece-Brasava, S., Murniece, I., DabinaBicka, I., Kozlinskis, E., Sarvi, S. (2011): Influence of PLA film packaging on the shelf life of soft cheese. International Scholary and Scientific Research \& Inovation 5 (8), 441-447.

30. Duncan, S.E., Webster, J.B., Steve, L.T. (2009): Sensory impacts of food packaging interactions. Advances in Food and Nutrition Research 56, 17-64. https://doi.org/10.1016/S1043-4526(08)00602-5

31. Duncan, T.V. (2011): Applications of nanotechnology in food packaging and food safety: barrier materials: antimicrobials and sensors. Journal of Colloid and Interface Science 363, 1-24. https://doi.org/10.1016/j.jcis.2011.07.017

32. Dutta, P., Tripathi, S., Mehrotra, G., Dutta, J. (2009): Perspectives for chitosan based antimicrobial films in food applications. Food Chemistry 114, 1173-1182. https://doi.org/10.1016/j.foodchem.2008.11.047 
33. Eliot, S.C., Vuillemard, J.C., Emond, J.P. (1998): Stability of shredded Mozzarella cheese under modified atmospheres. Journal of Food Science 63 (6), 1075-1080. https://doi.org/10.1111/j.1365-2621.1998.tb15858.x

34. Esmer, O.K., Balkir, P., Seckin, A.K., Irkin, R. (2009): Microbiological, Sensory and Textural Properties of Crottin de Chavignol Cheese. Food Science and Technology Research 15 (4), 367-376. https://doi.org/10.3136/fstr.15.367

35. Fajardo, P., Martins, J.T., Fuciños, C., Pastrana, L., Teixeira, J.A., Vicente, A.A. (2010): Evaluation of a chitosan-based edible flm as carrier of natamycin to improve the storability of Saloio cheese. Journal of Food Engineering 101 (4), 349-356. https://doi.org/10.1016/j.jfoodeng.2010.06.029

36. Falguera, V, Quintero, J.P., Jiménez, A., Muñoz, J.A., Ibarz, A. (2011): Edible films and coatings: Structures, active functions and trends in their use. Trends in Food Science \& Technology 22, 292-303. https://doi.org/10.1016/j.tifs.2011.02.004

37. Farber, J.N., Harris, L.J., Parish, M.E., Beuchat, L.R., Suslow, T.V., Gorney, J.R., Garrett, E.H., Busta, F.F. (2003): Microbiological safety of controlled and modified atmosphere packaging of fresh and fresh cut produce. Comprehensive Reviews in Food Science and Food Safety 2, 142-160. https://doi.org/10.1111/j.1541-4337.2003.tb00032.x

38. Favati, F., Galgano, F., Pace, A.M. (2007): Shelf-life evaluation of portioned Provolone cheese packaged in protective atmosphere. LWT-Food Science and Technology 40 (3), 480-488.

https://doi.org/10.1016/j.lwt.2005.12.001

39. Fernández, A., Cava, D., Ocio, M.J., Lagarón, J.M. (2008): Perspectives for biocatalysts in food packaging. Trends in Food Science \& Technology 19, 198-206. https://doi.org/10.1016/j.tifs.2007.12.004

40. Frederiksen, C.S., Haugaard, V.K., Poll, L., Becker, E.M. (2003): Light-induced quality changes in plain yoghurt packed in polylactate and polystyrene. European Food Research and Technology 217, 61-69. https://doi.org/10.1007/s00217-003-0722-3

41. Gamage, G.R., Park, H.J., Kim, K.M. (2009): Effectiveness of antimicrobial coated oriented polypropylene/polyethylene films in sprout packaging. Food Research International, 42 , 832-839. https://doi.org/10.1016/j.foodres.2009.03.012

42. Gammariello, D., Conte, A., Di Giulio, S., Attanasio, M., Del Nobile, M.A. (2009) Shelf life of Stracciatella cheese under modified-atmosphere packaging. Journal of Dairy Science 92 (2), 483-490.

https://doi.org/10.3168/jds.2008-1571

43. Garabal, J.I., Rodríguez-Alonso, P., Franco, D., Centeno, J.A. (2010): Chemical and biochemical study of industrially produced San Simón da Costa smoked semi-hard cow's milk cheeses: effects of storage under vacuum and different modified atmospheres. Journal of Dairy Science 93 (5), 1868-1881. https://doi.org/10.3168/jds.2009-2749

44. Gerschenson, L.N., Jagus, R., Olle Resa, C.P. (2018): Biodegradable Packaging Applied to Dairy Products. Advances in Dairy Products, $1^{\text {st }}$ Edition. Ed. by Francesco Contò, Matteo A. Del Nobile, Michele Faccia, Angelo V. Zambrini, and Amalia Conte. John Wiley \& Sons Ltd.
45. Goddard, J.M.; Talbert, J.N.; Hotchkiss, J.H. (2007): Covalent attachment of lactase to low-density polyethylene films. Journal of Food Science 72, 36-41. https://doi.org/10.1111/j.1750-3841.2006.00203.x

46. Gomes, C., Castell-Perez, M.E., Chimbombi, E., Barros, F., Sun, D., Liu, J., Sue, H.J., Sherman, P., Dunne, P., Wright, A.O. (2009): Effect of Oxygen-absorbing packaging on the shelf life of a liquid-based component of military operational rations. Journal of Food Science 74, 167-176. https://doi.org/10.1111/j.1750-3841.2009.01120.x

47. Gopirajah, R., Anandharamakrishnan, C. (2017): Packaging of Dried Dairy Products In Handbook of Drying for Dairy products (Anandharamakrishnan, C., ed). Wiley Blackwell, UK. pp. 229-248. https://doi.org/10.1002/9781118930526.ch11

48. Grosová, Z., Rosenberg, M., Rebros, M., Sipocz, M., Sedlackova, B. (2008): Entrapment of $\beta$-galactosidase in polyvinylalcohol hydrogel. Biotechnology Letters 30, 763-767. https://doi.org/10.1007/s10529-007-9606-0

49. Gün, I., Güzel-Seydim, Z., Seydim, A. (2009): The effect of modified atmosphere packaging on some properties of various types of cheese. Gida 34, 309-316.

50. Haghighi-Manesh, S., Azizi, M.H. (2017): Active packaging systems with emphasis on its applications in dairy products. Journal of Food Process Engineering 40 (5), 1-13. https://doi.org/10.1111/jfpe.12542

51. Han, J.H. (2005): New technologies in food packaging: overview. In: Han JH (ed) Innovations in food packaging. Academic, London, pp 3-11. https://doi.org/10.1016/B978-012311632-1/50033-4

52. Hansen, A.P., Arora, DK. (1990): Loss of flavour compounds from aseptically processed food-products packaged in aseptic containers. ACS Symposium Series 423, 318-332.

53. Hanusova, K., Stastna, M., Votavova, L., Klaudisova, K., Dobias, J., Voldrich, M., Marek, M. (2010): Polymer films releasing nisin and/or natamycin from polyvinyldichloride lacquer coating: Nisin and natamycin migration, efficiency in cheese packaging. Journal Food Engineering 99, 491496. https://doi.org/10.1016/j.jfoodeng.2010.01.034

54. Hoang, L.C., Chaine, A., Gregoire, L., Wache, Y. (2010): Potential of nisin incorporated sodium caseinate films to control Listeria in artificially contaminated cheese. Food Microbiology 27, 940-944. https://doi.org/10.1016/j.fm.2010.05.025

55. Irkin, R., Esmer, O.K. (2015): Novel food packaging systems with natural antimicrobial agents. Journal of Food Science and Technology 52 (10), 6095-6111. https://doi.org/10.1007/s13197-015-1780-9

56. Jalal, N., Surendranath, A.R., Pathaka, J.L., Yua, S., Chung, C.Y. (2018): Bisphenol A (BPA) the mighty and the mutagenic. Toxicology Reports 5, 76-84. https://doi.org/10.1016/j.toxrep.2017.12.013

57. Jalilzadeh, A., Tunçtürk, Y., Hesari, J. (2015): Extension Shelf Life of Cheese: A Review. International Journal of Dairy Science 10 (2), 44-60. https://doi.org/10.3923/ijds.2015.44.60

58. Jayamanne, V.S., Adams, M.R. (2004): Survival of probiotic bifidobacteria in buffalo curd and their effect on sensory properties. International Journal of Food Science and Technology 39 (7), 719-725. https://doi.org/10.1111/j.1365-2621.2004.00835.x 
59. Jin, T. (2010): Inactivation of Listeria monocytogenes in skim milk. Journal of Food Science 75 (2), 83-88. https://doi.org/10.1111/j.1750-3841.2009.01480.x

60. Jin, T., Liu, L., Zhang, H., Hicks, K. (2009): Antimicrobial activity of nisin incorporated in pectin and polylactic acid composite films against Listeria monocytogenes. International Journal of Food Science \& Technology, 44, 322-329.

https://doi.org/10.1111/j.1365-2621.2008.01719.x

61. Johnson, D.S., Duncan, S.E., Bianchi, L.M., Chang, H.H., Eigel, W.N., O'Keefe, S.F. (2015): Packaging modifications for protecting flavor of extended-shelf-life milk from light. Journal of Dairy Science 98, 1-10. https://doi.org/10.3168/jds.2014-8857

62. Juric, M., Bertelsen, G., Mortensen, G., Petersen, M.A. (2003): Light-induced colour and aroma changes in sliced, modified atmosphere packaged semi-hard cheeses. International Dairy Journal 13 (2-3), 239-249. https://doi.org/10.1016/S0958-6946(02)00156-5

63. Kallinteri, L.D., Kostoula, O.K., Savvaidis, I.N. (2013): Efficacy of nisin and/or natamycin to improve the shelflife of Galotyri cheese. Food Microbiology 36, 176-181. https://doi.org/10.1016/j.fm.2013.05.006

64. Kanatt, S.R., Rao, M., Chawla, S., Sharma, A. (2012): Active chitosan-polyvinyl alcohol films with natural extracts. Food Hydrocolloids 29, 290-297. https://doi.org/10.1016/j.foodhyd.2012.03.005

65. Kang, J.H., Kondo, F. (2003): Determination of bisphenol $A$ in milk and dairy products by high-performance liquid chromatography with fluorescence detection. Journal of Food Protection 66 (8), 1439-43. https://doi.org/10.4315/0362-028X-66.8.1439

66. Karaman, A.D., Özer, B., Pascall, M.A., Alvarez, V. (2015): Recent Advances in Dairy Packaging. Food reviews International 31, 295-318. https://doi.org/10.1080/87559129.2015.1015138

67. Kavas, G., Kavas, N. (2016): Use of egg white protein powder based films fortified with sage and lemon balm essential oils in the storage of lor cheese. Mljekarstvo 66 (2), 99-111.

68. Kechichian, V., Ditchfield, C., Veiga-Santos, P., Tadini, C. C. (2010): Natural antimicrobial ingredients incorporated in biodegradable films based on cassava starch. LWT - Food Science and Technology 43, 1088-1094. https://doi.org/10.1016/j.lwt.2010.02.014

69. Khoshgozaran, S., Azizi, M.H., Bagheripoor-Fallah, N. (2012): Evaluating the effect of modified atmosphere packaging on cheese characteristics: a review. Dairy Science \& Technology 92, 1-24. https://doi.org/10.1007/s13594-011-0044-3

70. Khwaldia, K., Perez, C., Banon S., Desobry, S., Hardy, J. (2004): Milk proteins for edible films and coatings. Critical Reviews in Food Science and Nutrition 44 (4), 239-25. https://doi.org/10.1080/10408690490464906

71. Kim, B., Kim, D., Cho, D., Cho, S. (2003): Bactericidal effect of $\mathrm{TiO}_{2}$ photocatalyst on selected food-borne pathogenic bacteria. Chemosphere 52, 277-281. https://doi.org/10.1016/S0045-6535(03)00051-1
72. Kristensen, D., Orlien, V., Mortensen, G., Brockhoff, P., Skibsted, L.H. (2000): Light-induced oxidation in sliced Havarti cheese packaged in modified atmosphere. International Dairy Journal 10, 95-103. https://doi.org/10.1016/S0958-6946(00)00028-5

73. Kudelka, W. (2005): Changes in the acidity of fermented milk products during their storage as exemplified by natural bio-yoghurts. Milchwissenschaft 60, 294-296.

74. Kuorwel, K.K., Cran, M. J., Sonneveld, K., Miltz, J., Bigger, S. W. (2011): Antimicrobial activity of biodegradable polysaccharide and protein-based films containing active agents. Journal of Food Science 76 (3), R90-R102. https://doi.org/10.1111/j.1750-3841.2011.02102.x

75. Lee, C.H., An, D.S., Lee, S.C., Park, H.J., Lee, D.S. (2004): A coating for use as an antimicrobial and antioxidative packaging material incorporating nisin and a-tocopherol. Journal of Food Engineering 62 (4), 323-329. https://doi.org/10.1016/S0260-8774(03)00246-2

76. Lee, C.H., An, D.S., Park, H.J., Lee, D.S. (2003): Widespectrum antimicrobial packaging materials incorporating nisin and chitosan in the coating. Packaging Technology and Science 16, 99-106. https://doi.org/10.1002/pts.617

77. Lopez-Rubio, A., Almenar, E., Hernandez-Munoz, P., Lagaron, J.P., Catala, R., Gavara, R. (2004): Overview of Active Polymer-Based Packaging Technologies for Food Applications. Food Reviews International 20 (4), 357-387. https://doi.org/10.1081/FRI-200033462

78. Lopez, P., Sanchez, C., Batlle, R., Nerín, C. (2007): Development of flexible antimicrobial films using essential oils as active agents. Journal of Agricultural and Food Chemistry 55, 8814-8824. https://doi.org/10.1021/jf071737b

79. Mahoney, K.W., Talbert, J.N., Goddard, J.M. (2013): Effect of polyethylene glycol tether size and chemistry on the attachment of lactase to polyethylene films. Journal of Applied Polymer Science 127, 1203-1210. https://doi.org/10.1002/app.37622

80. Maniar, A.B., Marcy, J.E., Bishop, J.R., Duncan, S.E. (1994): Modified atmosphere packaging to maintain direct set Cottage cheese quality. Journal of Food Science 59 (6), 1305-1308. https://doi.org/10.1111/j.1365-2621.1994.tb14701.x

81. Maragou, N.C, Lampi, E.N., Thomaidis, N.S., Koupparis, M.A., (2006): Determination of bisphenol A in milk by solid phase extraction and liquid chromatography-mass spectrometry. Journal of Chromatography A 1129 (2), 165-173. https://doi.org/10.1016/j.chroma.2006.06.103

82. Martin, N.H., Carey, N.R., Murphy, S.C., Wiedmann, M., Boor, K.J. (2012): A decade of improvement: New York State fluid milk quality. Journal of Dairy Science 95, 7384-7390. https://doi.org/10.3168/jds.2012-5767

83. Martins, J.T., Cerquerira, M.A., Souza, B.W.S., Avides, M.C., Vicente, A.A. (2010): Shelf life of Ricotta cheese using coatings of galactomannans from nonconventional sources incorporating nisin against Listeria monocytogenes. Journal of Agriculutral and Food Chemistry 58, 1884-1891. https://doi.org/10.1021/jf902774z 
84. Mchugh, T., Krochta, J. (1994): Sorbitol- vs. glycerolplasticized whey protein edible films: integrated oxygen permeability and tensile property evaluation. Journal of Agricultural and Food Chemistry 42 (2), 841-845. https://doi.org/10.1021/jf00040a001

85. Mcsweeny, P.L.H. (2007): Cheese problems solved. CRC Press, Boca Raton, USA.

86. Mehar Afroz, Q., Swaminathan, K., Karthikeyan, P., Ahmed, P., Sudhir, U., Mishra, U., Kumar, M. (2012): Application of nanotechnology in food and dairy processing: An overview. Pakistan Journal of Food Sciences 22 (1), 23-31.

87. Miller, C., Nguyen, M., Rooney, M., Kailasapthy, K. (2003a): The influence of packaging materials on the dissolved oxygen content of probiotic yogurt. Packaging Technology and Science 15, 133-138. https://doi.org/10.1002/pts.578

88. Miller, C.W., Nguyen, M.H., Rooney, K., Kailasapathy, K. (2003b): The control of dissolved oxygen content in probiotic yogurts by alternative packing materials. Packaging Technology and Science 16, 61-67. https://doi.org/10.1002/pts.612

89. Mohammadi, V., Ghasemi-Varnamkhasti, M., González, L. (2017): Analytical measurements of ultrasound propagation in dairy products: A review. Trends in Food Science \& Technology 61, 38-41. https://doi.org/10.1016/j.tifs.2016.12.004

90. Moraes, A., Gouveia, L., Soares, N., Santos, M., Goncalves, M. (2007): Development and evaluation of antimicrobial film on butter conservation. Ciencia Tecnolgica Alimentaria 27, 33-36. https://doi.org/10.1590/S0101-20612007000500006

91. Moreira, M.R., Pereda, M., Marcovich, N.E., Roura, S.I. (2011): Antimicrobial effectiveness of bioactive packaging materials from edible chitosan and casein polymers: Assessment on carrot, cheese, and salami. Journal of Food Science 76 (1), M54-M63. https://doi.org/10.1111/j.1750-3841.2010.01910.x

92. Moro, A., Berruga, M.I., Zalacain, A., Carmona, M. (2013): Mycotoxicogenic fungal inhibition by innovative cheese cover with aromatic plants. Journal of the Science of Food and Agriculture 93, 1112-1118.

https://doi.org/10.1002/jsfa.5859

93. Mullan, M., McDowell, D. (2003): Modified atmosphere packaging. In Food packaging technology (Coles R, McDowell D, Kirwan M.J., eds). Blackwell, Oxford, pp 303339.

94. O'Callaghan, K.A.M., Kerry, J.P. (2016): Consumer attitudes towards the application of smart packaging technologies to cheese products. Food Packaging and Shelf Life 9, 1-9. https://doi.org/10.1016/j.fpsl.2016.05.001

95. Olarte, C., Gonzalez-Fandos, E., Gimenez, M., Sanz, S., Portu, J. (2002) The growth of Listeria monocytogenes in fresh goat cheese (Cameros cheese) packaged under modified atmospheres. Food Microbiology 19 (1), 75-82. https://doi.org/10.1006/fmic.2001.0456

96. Ollé Resa, C.P., Gerschenson, L.N., Jagus, R.J. (2014): Natamycin and nisin supported on starch edible films for controlling mixed culture growth on model systems and Port Salut cheese. Food Control 44, 146-151. https://doi.org/10.1016/j.foodcont.2014.03.054
97. Ouattara, B., Simard, R.E., Piette, G., Begin, A., Holley, R.A. (2000): Inhibition of surface spoilage bacteria in processed meats by application of antimicrobial films prepared with chitosan. International Journal of Food Microbiology 62, 139-148. https://doi.org/10.1016/S0168-1605(00)00407-4

98. Pang, Z., Deeth, H., Sharma, R., Bansal, N. (2015): Effect of addition of gelatin on the rheological and microstructural properties of acid milk protein gels. Food Hydrocolloids 43, 340-351.

https://doi.org/10.1016/j.foodhyd.2014.06.005

99. Papaioannou, G., Chouliara, I., Karatapanis, A.E., Kontominas, M.G., Savvaidis, I.N. (2007): Shelf-life of a Greek whey cheese under modified atmosphere packaging. International Dairy Journal 17, 358-364. https://doi.org/10.1016/j.idairyj.2006.04.001

100. Perkins, M., Zerdin, K., Rooney, L., D’arcy, B., Deeth, C. (2007): Active packaging of UHT milk to prevent the development of stale flavor during storage. Packaging Technology and Science 20, 137-146. https://doi.org/10.1002/pts.749

101. Petersen, K., Væggemose, Nielsen P., Bertelsen, G., Lawther, M., Olsen, M. B., Nilsson, N. H., Mortensen, G. (1999): Potential of biobased materials for food packaging. Trends in Food Science \& Technology 10, 52-68. https://doi.org/10.1016/S0924-2244(99)00019-9

102. Pintado, M.E., Malcata, F.X. (2000): Optimization of modified atmosphere packaging with respect to physicochemical characteristics of Requeijão. Food Research International 33, 821-832. https://doi.org/10.1016/S0963-9969(00)00078-8

103. Poças, M.F., Pintado, M. (2010): Packaging and the shelf life of cheese. In Food Packaging and Shelf Life: A Pratical Guide (G.L. Robertson, Ed), Boca Raton, FL: CRC Press, pp 103-125.

104. Ramos, M., Valdés, A., Mellinas, A.C., Garrigós, M.C. (2015): New Trends in Beverage Packaging Systems: A Review. Beverages 1, 248-272. https://doi.org/10.3390/beverages 1040248

105. Rathore, S., Desai, M.P., Liew, C.V., Chan, L.W., Heng, P.W.S. (2013): Microcapsulation of microbial cells. Journal of Food Engineering 116, 369-381. https://doi.org/10.1016/j.jfoodeng.2012.12.022

106. Ravichandran, R. (2010): Nanoparticles in drug delivery: potential greennanobiomedicine applications. International Journal of Biomedical Nanoscience and Nanotechnology 1 , 108-130.

107. Ravishankar, S., Jaroni, D., Zhu, L., Olsen, C., Mchugh, T., Friedman, M. (2012): Inactivation of Listeria monocytogenes on ham and bologna using pectinbased apple, carrot, and hibiscus edible films containing carvacrol and cinnamaldehyde. Journal of Food Science 77, M377-M382. https://doi.org/10.1111/j.1750-3841.2012.02751.x

108. Realini, C.E., Marcos, B. (2014): Active and intelligent packaging systems for a modern society. Meat Science 98 , 404-419. https://doi.org/10.1016/j.meatsci.2014.06.031 
109. Ren, G., Hu, D., Cheng, E.W., Vargas-Reus, M.A., Reip, P. Allaker, R.P. (2009): Characterisation of copper oxide nanoparticles for antimicrobial applications. International Journal of Antimicrobial Agents 33 (6), 587-590. https://doi.org/10.1016/j.ijantimicag.2008.12.004

110. Robertson, G.W. (2016): Packaging of Dairy Products. In Food Packaging: Principles and Practice, Third Edition. CRC Press, Taylor \& Francis Group, pp. 509-540.

111. Rodriguez-Aguilera, R.; Oliveira, J.C. (2009): Review of Design Engineering Methods and Applications of Active and Modified Atmosphere Packaging Systems. Food Engineering Reviwes 1, 66-83. https://doi.org/10.1007/s12393-009-9001-9

112. Rodriguez-Aguilera, R., Oliveira, J.C., Montanez, J.C., Mahajan, P.V. (2011): Effect of modified atmosphere packaging on quality factors and shelf-life of surface mould ripened cheese: Part I constant temperature. LWT Food Science and Technology 44, 330-336. https://doi.org/10.1016/j.Iwt.2010.06.015

113. Rodriguez-Lafuente, A., Nerin, C., Batlle, R. (2010): Active paraffinbased paper packaging for extending the shelf life of cherry tomatoes. Journal of Agricultural and Food Chemistry 58, 6780-6786. https://doi.org/10.1021/jf100728n

114. Romero, E.P., Ros-Lis, J.V., Vivancos, J-L., Martínez-Máñez, R. (2017): Recent advances on intelligent packaging as tools to reduce food waste. Journal of Cleaner Production 172, 3398-3409.

115. Ruparelia, J.P., Chatterjee, A.K., Duttagupta, S.P., Mukherji, S. (2008). Strain specificity in antimicrobial activity of silver and copper nanoparticles. Acta Biomaterialia 4, 707-716. https://doi.org/10.1016/j.actbio.2007.11.006

116. Saint-Eve, A., Levy, C., Le Moigne, M., Ducruet, V., Souchon, I. (2008): Quality changes in yogurt during storage in different packaging materials. Food Chemistry 110 (2), 285-293. https://doi.org/10.1016/j.foodchem.2008.01.070

117. Sanches-Silva, A., Cruz-Freire, J. M., Sendón, R., Franz, R., Paseiro-Losada, P. (2007): Determination of butylated hydroxytoluene in food samples by ultroviolet detection and gas chromatography/mass spectrometry. Journal of AOAC International 90, 277-283.

118. Sanches-Silva, A., Cruz-Freire, J. M., Sendón, R., Franz, R., Paseiro-Losada, P. (2009): Migraton and diffusion of diphenylbutadiene from packages into foods. Journal of Agricultural and Food Chemistry 57, 10225-10230. https://doi.org/10.1021/jf901666h

119. Sanla-Ead, N., Jangchud, A., Chonhenchob, V., Suppakul, P. (2012): Antimicrobial activity of cinnamaldehyde and eugenol and their activity after incorporation into cellulose-based packaging films. Packaging Technology and Science 25, 7-17. https://doi.org/10.1002/pts.952

120. Santonicola, S., Ibarra, V.G., Sendón, R., Mercogliano, R., Rodríguez-Bernaldo de Quirós, A. (2017): Antimicrobial Films Based on Chitosan and Methylcellulose Containing Natamycin for Active Packaging Applications. Coatings 7 , 177. https://doi.org/10.3390/coatings7100177
121. Singh, P., Wani, A.A., Karim, A.A., Langowski, H-C. (2012): The use of carbon dioxide in the processing and packaging of milk and dairy products: A review. International Journal of Dairy Technology 65 (2), 161-177. https://doi.org/10.1111/j.1471-0307.2011.00744.x

122. Sinigaglia, M., Bevilacqua, A., Corbo, M.R., Pati, S., Del Nobile, M.A. (2008): Use of active compounds for prolonging the shelf life of mozzarella cheese. International Dairy Journal 18, 624-630. https://doi.org/10.1016/j.idairyj.2007.11.022

123. Sobrino-Lopez, A., Martín-Belloso, O. (2008): Use of nisin and other bacteriocins for preservation of dairy products. International Dairy Journal 18, 329-343. https://doi.org/10.1016/j.idairyj.2007.11.009

124. Talwalkar, A., Miller, C., Kailasapathy, K., Nugyen, M. (2004): Effect of packaging conditions and dissolved oxygen on the survival probiotic bacteria in yoghurt. International Journal of Food Science and Technology 39, 605-611. https://doi.org/10.1111/j.1365-2621.2004.00820.x

125. Temiz, H., Aykut, U., Hurşit, A.K. (2009): Shelf life of Turkish whey cheese (Lor) under modified atmosphere packaging. International Journal of Dairy Technology 62(3), 378-386. https://doi.org/10.1111/j.1471-0307.2009.00511.x

126. Tripathi, M.K., Gri, S.K. (2014): Probiotic functional foods: Survival of probiotics during processing and storage. Journal of Functional Foods 9, 225-241. https://doi.org/10.1016/j.jf.2014.04.030

127. Trobetas, A., Badeka, A., Kontominas, M.G. (2008): Light-induced changes in grated Graviera hard cheese packaged under modified atmospheres. International Dairy Journal 18 (12), 1133-1139. https://doi.org/10.1016/j.idairyj.2008.06.002

128. Ünalan, I..U., ARcan, I., Korel, F., Yemenicioğlu, A. (2013): Application of active zein- based flms with controlled release properties to control Listeria monocytogenes growth and lipid oxidation in fresh Kashar cheese. Innovative Food Science \& Emerging Technologies 20, 8-214. https://doi.org/10.1016/j.ifset.2013.08.004

129. Vermeiren, L., Devlieghere, F., Van Beest, M., De Kruijf, N., Debevere, J. (1999): Developments in the active packaging of foods. Trends Food Science and Technology 10, 77-86. https://doi.org/10.1016/S0924-2244(99)00032-1

130. Wang, R.H., Xin, J.H. Tao, X.M. (2005): UV-blocking property of dumbbell-shaped ZnO crystallites on cotton fabrics. Inorganic Chemistry 44, 3926-3930. https://doi.org/10.1021/ic0503176

131. Wong, A., Chan, C.Y., Chau, C.T., Chow, C.Y., Hung, T.Y., Mui, L.Y., Tai, Y.L. (2017): Levels of bisphenol A in milk and dairy products in Hong Kong market by high performance liquid chromatography. Journal of Chromatographic Separation and Technology 8 (4).

132. Wong, D.E., Goddard, J.M. (2014): Short communication: Effect of active food packaging materials on fluid milk quality and shelf life. Journal of Dairy Science 97, 166-172. https://doi.org/10.3168/jds.2013-7214

133. Wu, Y.M., Hu, C.Y., Wang, L., Cheng, J., Wang, Z.W., Zhu, Y. (2010): Migration of Contaminats from Packaging Materials into Dairy Products. Proceedeings of the $17^{\text {th }}$ World Conference of Packaging, 207-211.

134. Zabbia, A. (2009): New packing improves UHT milk flavour. Food Reviews 36, 38-39. 